\title{
Article \\ Quantitative HBsAg versus HBV DNA in Predicting Significant Hepatitis Activity of HBeAg-Positive Chronic HBV Infection
}

\author{
Zhanqing Zhang ${ }^{1, *,+}$, Wei Lu ${ }^{1,+}$, Dong Zeng ${ }^{2,+}$, Dan Huang ${ }^{1}$, Weijia Lin ${ }^{1}$, Li Yan ${ }^{1}$ and Yanling Feng ${ }^{2}$ \\ 1 Department of Hepatobiliary Medicine, Shanghai Public Health Clinical Center of Fudan University, \\ Shanghai 201508, China; luwei@shphc.org.cn (W.L.); huangdan@shphc.org.cn (D.H.); \\ linweijia@shphc.org.cn (W.L.); yanli10389@shphc.org.cn (L.Y.) \\ 2 Department of Clinical Pathology, Shanghai Public Health Clinical Center of Fudan University, \\ Shanghai 201508, China; zengdong@shphc.org.cn (D.Z.); fengyanling@shphc.org.cn (Y.F.) \\ * Correspondence: doctorzzq@shphc.org.cn; Tel.: +86-21-37990333 (ext. 3245) \\ + These authors contributed equally to this work.
}

check for updates

Citation: Zhang, Z.; Lu, W.; Zeng, D.; Huang, D.; Lin, W.; Yan, L.; Feng, Y. Quantitative HBsAg versus HBV DNA in Predicting Significant Hepatitis Activity of HBeAg-Positive Chronic HBV Infection. J. Clin. Med. 2021, 10, 5617. https://doi.org/ $10.3390 / \mathrm{jcm} 10235617$

Academic Editors: Sandra Ciesek and Marco Sebastiani

Received: 23 September 2021

Accepted: 24 November 2021

Published: 29 November 2021

Publisher's Note: MDPI stays neutral with regard to jurisdictional claims in published maps and institutional affiliations.

Copyright: (c) 2021 by the authors. Licensee MDPI, Basel, Switzerland. This article is an open access article distributed under the terms and conditions of the Creative Commons Attribution (CC BY) license (https:// creativecommons.org/licenses/by/ $4.0 /)$.

\begin{abstract}
Background: As specialparameters in predicting significant hepatitis activity of hepatitis $\mathrm{B}$ e antigen (HBeAg)-positive chronic hepatitis B virus (HBV) infection, the quantitative standard of HBV DNA has not been agreed and that of hepatitis B surface antigen(HBsAg) has not been formed. Our objective is to evaluate the validity of HBsAg and HBV DNA in predicting the significant hepatitis activity of HBeAg-positive patients. (2) Methods: A population of 516 patients with HBeAgpositive chronic HBV infection was enrolled. Serum ALT was measured using an Abbott Architect c16000 autoanalyzer; diagnoses of liver pathological grade and stage referred to the Scheuer standard. Three levels of significant hepatitis activity were preset, which were successively "ALT $\geq 20$ IU/L or Grade > G1 or Stage > S1", "ALT $\geq 30$ IU/L or Grade > G1 or Stage > S1" and "ALT $\geq 40$ IU/L or Grade > G1 or Stage > S1". (3) Results: A subpopulation of 288 patients with possible high HBV replication was selected based on locally weighted scatterplot smoothing regression curves between ALT and HBsAg, HBeAg and HBV DNA. In the subpopulation with possible high HBV replication, areas under receiver operating characteristic curves of HBsAg for predicting the three levels of significant hepatitis activity were successively $0.868,0.839$ and 0.789 , which were all significantly greater than those of HBV DNA, as those were successively $0.553,0.550$ and $0.574(p=0.0002$, $p<0.0001$ and $p<0.0001$ ). With the standard of HBsAg $\leq 4.699 \log _{10} \mathrm{IU} / \mathrm{mL}$, the sensitivity and specificity of HBsAg for predicting the three levels of significant hepatitis activity were successively $75.81 \%$ and $81.82 \%, 79.23 \%$ and $78.57 \%$ and $80.82 \%$ and $67.44 \%$. (4) Conclusion: Quantitative HBsAg instead of HBV DNA is valuable in predicting significant hepatitis activity of HBeAg-positive chronic HBV infection.
\end{abstract}

Keywords: chronic hepatitis B virus infection; natural history; significant hepatitis activity; hepatitis B surface antigen; hepatitis B virus DNA

\section{Introduction}

Chronic hepatitis B virus (HBV) infection remains a major public health issue affecting human health [1]. Liver cirrhosis, hepatocellular carcinoma and liver decompensation caused by persistent or recurring significant hepatitis activity are the main adverse consequences of chronic HBV infection. Nucleoside/nucleotide antiviral drugs are the main measures to limit significant hepatitis activity and prevent the adverse consequences of chronic HBV infection [2-4]. Accurately identifying significant hepatitis activity of chronic $\mathrm{HBV}$ infection is a prerequisite for the rational management of patients and reasonable use of antiviral drugs.

With reference to serum hepatitis $\mathrm{B}$ e antigen $(\mathrm{HBeAg})$ status and alanine transferase (ALT) and HBV DNA levels, the natural history of chronic HBV infection is generally divided into four consecutive but possibly reciprocating phases (See Appendices A.1 and A.2): 
(1) HBeAg-positive non-significant hepatitis activity, which is characterized by sustained normal ALT, fluctuating HBV DNA at high levels and sustained slight liver necro-inflammation with no or slight liver fibrosis; (2) HBeAg-positive significant hepatitis activity, which manifests as gradually or repeatedly elevated ALT, gradually or repeatedly decreased HBV DNA and gradually or repeatedly aggravated liver necro-inflammation with progressive liver fibrosis; (3) HBeAg-negative non-significant hepatitis activity, which is characterized by sustained normal ALT, fluctuating HBV DNA at low levels and slight liver necro-inflammation with gradually regressive liver fibrosis; and(4) HBeAg-negative significant hepatitis activity, which manifests as gradually or repeatedly elevated ALT, gradually or repeatedly increased HBV DNA and gradually or repeatedly aggravated liver necro-inflammationwith re-progressive liver fibrosis.

However, the upper limit of normal (ULN) for ALT is still controversial [2-5], and the delimitation of both ALT and HBV DNA levels in discriminating the natural history phases of chronic HBV infection is still not unified: (1) The rational reference value for ALT in predicting both HBeAg-positive and HBeAg-negative significant hepatitis activity is not conclusive yet [2-4], and the ability of ALT in predicting bothHBeAg-positive and HBeAg-negative liver fibrosis levels is limited [6-9]; (2) The rational cutoff value for HBV DNA in predicting HBeAg-positive significant hepatitis activity is not clear yet [2-4], and the validity of HBV DNA in predicting HBeAg-positive liver fibrosis levels is questioned $[2-4,10,11]$.

The established quantitative serum markers of HBV include hepatitis B surface antigen (HBsAg), $\mathrm{HBeAg}$, hepatitis B core-related antigen (HBcrAg), antibodies against hepatitis B core antigen (anti-HBc), HBV DNA and HBV RNA [11,12]. Among them, HBeAg and HBV RNA have not been standardized, and HBsAg has been promoted and applied [2-4]. In HBeAg-positive patients, HBsAg levels in the non-significant hepatitis activity phase were significantly higher than those in the significant hepatitis activity phase $[13,14]$, and HBsAg showed good performance in predicting significant hepatitis activity, significant liver fibrosis with ALT less than $2 \times$ ULN and liver cirrhosis without considering ALT levels [15-17]. However, in HBeAg-negative patients, HBsAg levels in the non-significant hepatitis activity phase were not necessarily significantly lower than those in the significant hepatitis activity phase $[13,14]$, and $\mathrm{HBsAg}$ had no value in predicting significant hepatitis activity and liver fibrosis levels [15-17].

The quantitative standard for HBsAg in predicting the significant hepatitis activity phase of HBeAg-positive chronic HBV infection has not been formed [2-4]. HBsAg is produced by both HBV covalently closed circular DNA (cccDNA) and HBV DNA integrated into the host genome [18-20]. HBV DNA integration begins at the very early stage of chronic HBV infection $[19,20]$, and the frequency of the integration in HBeAg-negative patients is significantly higher than that of HBeAg-positive patients [18-20]. Nevertheless, HBsAg in patients with HBeAg-positive chronic HBV infection was significantly positively correlated with HBV DNA $[13,14,21]$. In addition, the high levels of HBsAg associated with high other than medium or low HBV replication may contuse the host's immune responses against $\mathrm{HBV}$, which may be the direct key factor leading to non-significant hepatitis activity in patients with HBeAg-positive chronic HBV infection [15,22]. Therefore, the studies, whether by referring to the conventional phasing criteria of natural history that covers HBVDNA intrinsically related to the production of HBsAgor based on the overall population of HBeAg-positive stage that covers the subpopulation with low HBV replication, could not accurately obtain valuable information reflecting the performance of HBsAg in the prediction of HBeAg-positive significant hepatitis activity activity (See Appendices A.3-A.8).

The purpose of this study was to delimit the subpopulation with possible high and possible low HBV replication in a population with HBeAg-positive chronic HBV infection, and on this basis, to evaluate the performance of HBsAg, HBeAg and HBV DNA for predicting significant HBeAg-positive hepatitis activity. 


\section{Materials and Methods}

\subsection{Study Population}

HBeAg-positive patients with chronic HBV infection who were hospitalized and underwent liver biopsy in Shanghai Public Health Clinical Center of Fudan University from January 2017 to September 2020 were screened. A total of 516 patients with complete hospitalization records, detailed descriptions of liver pathology and matching laboratory data were enrolled for this study. Among them, 313 were males and 203 were females, and age ranged from 10 to 68 years with a median (interquartile range) of 34 (29-39) years; the proportions of patients with age $<25$ years and $<30$ years in males were $9.3 \%(29 / 313)$ and $30.0 \%(94 / 313)$, and in females were $6.4 \%(13 / 203)$ and $27.1 \%(55 / 203)$. Patients with the following conditions were excluded: coinfection with other hepatotropic viruses (hepatitis A, C, D and E virus), Epstein-Barr virus, cytomegalovirus; Schistosomiasis japonica liver disease, nonalcoholic/metabolic fatty liver disease (steatosis $>5 \%$ ), drug-induced liver injury, excessive drinking (equivalent to ethanol, male $>30 \mathrm{~g} /$ day, female $>20 \mathrm{~g} /$ day), autoimmune diseases, endocrine and metabolic diseases, gallstones and bile duct stones, liver tumors and decompensated liver disease; antiviral therapy with interferon- $\alpha /$ peginterferon- $\alpha$ or nucleosides/nucleotides, hepato-protective therapy with glycyrrhizates or oxymatrine/matrine or bicyclol/bifendate or traditional Chinese medicine prescriptions (including Chinese patent medicines) within 6 months before liver biopsy; length of biopsy specimen less than $1.0 \mathrm{~cm}$ or number of portal areas less than 6.

\subsection{Laboratory Assays}

Fasting venous blood was collected and serum was separated on the morning of liver biopsy. HBsAg and $\mathrm{HBeAg}$ were measured by microparticle enzyme immunoassay using an Abbott Architect i2000 automatic immunoassay system (Abbott Laboratories, Chicago, $\mathrm{IL}, \mathrm{USA}$ ) and auxiliary reagents. The detection range of $\mathrm{HBsAg}$ is 0.05 to $250 \mathrm{IU} / \mathrm{mL}$, and a sample was diluted by 500 times and re-measured if HBsAg exceeded the upper limit of detection; the lower limit of detection of HBeAg is 1.0 SCO. HBV DNA was measured by PCR probe assay using a Roche LightCycler 480 qPCR system (Roche, Basel, Switzerland), the reagents were purchased from Sansure Biotech Inc. (Changsha, China) and the detection range of HBV DNA is $1 \times 10^{2}$ to $2 \times 10^{9} \mathrm{IU} / \mathrm{mL}$. ALT was measured using an Abbott Architect c16000 automatic biochemical analysis system (Abbott Laboratories, Chicago, IL, USA) and auxiliary reagents. Based on related literature [2-5], three levels of ULNs for ALT were preset in this study, which were successively $20 \mathrm{IU} / \mathrm{L}, 30 \mathrm{IU} / \mathrm{L}$ and $40 \mathrm{IU} / \mathrm{L}$, and "ALT $\geq$ ULNs" were defined as biochemically significant hepatitis activity.

\subsection{Pathological Diagnoses}

Percutaneous suction liver biopsies assisted by ultrasonography were performed using a 16G biopsy needle after written informed consent forms were signed. The biopsy specimens were immediately transferred into plastic tubes, quickly frozen and processed within $36 \mathrm{~h}$. The quality assessments and pathological diagnoses of biopsy specimens were performed independently by one experienced pathologist, who was ignorant of the laboratory information. The pathological diagnoses of liver specimens referred to the Scheuer scoring system [23], in which the intensity of necro-inflammation is divided into five grades ranging from G0 to G4, and the degree of fibrosis and alteration of architecture is divided into five stages ranging from S0 to S4. In this study, "Grade > G1 or Stage > S1" was defined as pathologically significant hepatitis activity.

\subsection{Statistical Analyses}

MedCalc version 15.8 (MedCalc Software, Mariakerke, Belgium) was used for statistical analyses and graph productions. Locally weighted scatterplot smoothing (LOESS) regression analysis was used to explore the evolving trend between ALT and HBsAg, HBeAg and HBV DNA, and to delimit the subpopulations with possible high and possible low HBV replication. Mann-WhitneyU non-parametric test was used to compare the 
differences in ALT, HBsAg, HBeAg and HBV DNA levels between subpopulations with possible high and with possible low HBV replication. Spearman rank correlation analysis was used to analyze the correlations between ALT, liver pathological grade and stage and $\mathrm{HBsAg}, \mathrm{HBeAg}$ and HBV DNA. Fisher $Z$ non-parametric test was used to compare the differences in Spearman correlation coefficients between ALT, liver pathological grade and stage and HBsAg, HBeAg and HBV DNA between each other. Receiver operating characteristic (ROC) curve was used to evaluate the performance of $\mathrm{HBsAg}, \mathrm{HBeAg}$ and HBV DNA for predicting "biochemical or pathological" significant hepatitis activity in the subpopulation with possible high HBV replication and for predicting biochemically significant hepatitis activity in the subpopulation with possible low HBV replication. Dependent sample Hanley and McNeil $Z$ nonparametric test was used to compare the differences in areas under ROC curves (AUCs) between $\mathrm{HBsAg}, \mathrm{HBeAg}$ and HBV DNA for predicting significant hepatitis activity. $p<0.05$ was defined as statistically significant.

\section{Results}

\subsection{Delimitation of Subpopulation with Possible High and Possible Low HBV Replication}

HBsAg, HBeAg and HBV DNA were used as independent variables, ALT was used as a dependent variable and LOESS regression analyses were performed with a span of $60 \%$. The LOESS regression curves between ALT and HBsAg, HBeAg and HBV DNA are illustrated in Figure 1.

According to the LOESS regression curves, $\mathrm{HBsAg}, \mathrm{HBeAg}$ and HBV DNA levels could be divided into two strata of high and medium-low levels: HBsAg $>4.250$ and $\leq 4.250 \log _{10} \mathrm{IU} / \mathrm{mL}, \mathrm{HBeAg}>2.875$ and $\leq 2.875 \log _{10} \mathrm{SCO}$ and HBV DNA $>7.500$ and $\leq 7.500 \log _{10} \mathrm{IU} / \mathrm{mL}$. The proportions of ALT $\geq 20 \mathrm{IU} / \mathrm{L}, \geq 30 \mathrm{IU} / \mathrm{L}$ and $\geq 40 \mathrm{IU} / \mathrm{L}$ in patients with high levels of HBsAg were $92.0 \%$ (161/175), 79.4\% (139/175) and 70.9\% (124/175), with high levels of HBeAg were $93.6 \%(221 / 236), 84.7 \%(200 / 236)$ and $77.1 \%$ $(182 / 236)$, and with high levels of HBV DNA were $94.4 \%(184 / 195), 85.1 \%(166 / 195)$ and $77.4 \%(151 / 195)$.

With the standard of the quantitative stratification of HBsAg, HBeAg and HBV DNA, the subpopulations with possible high $\mathrm{HBV}$ replication and possible low $\mathrm{HBV}$ replication were defined as "HBsAg $>4.250 \log _{10} \mathrm{IU} / \mathrm{mL}$ or HBeAg $>2.875 \log _{10} \mathrm{SCO}$ or HBV DNA > $7.500 \log _{10} \mathrm{IU} / \mathrm{mL}^{\prime}$ and "HBsAg $\leq 4.250 \log _{10} \mathrm{IU} / \mathrm{mL}$ and $\mathrm{HBeAg} \leq 2.875 \log _{10}$ $\mathrm{SCO}$ and HBV DNA $\leq 7.500 \log _{10} \mathrm{IU} / \mathrm{mL}$ ". In the subpopulation with possible high HBV replication, the proportions of patients with high levels of $\mathrm{HBsAg}$, $\mathrm{HBeAg}$ and $\mathrm{HBV}$ DNA were $60.8 \%(175 / 288), 81.9 \%(236 / 288)$ and $67.7 \%(195 / 288)$.

\subsection{Demographic, Laboratory and Pathological Characteristics of Study Population}

The demographic, laboratory and pathological characteristics of the overall population and of the subpopulations with possible high and possible low HBV replication are summarized in Table 1.

In the subpopulation with possible high HBV replication, the proportions of patients with age $<25$ years and $<30$ years in males were $8.4 \%(15 / 179)$ and $33.0 \%(59 / 179)$, and in females were $6.4 \%(7 / 109)$ and $24.8 \%(27 / 109)$. In the subpopulation with possible low HBV replication, the proportions of patients with age $<25$ years and $<30$ years in males were $10.4 \%(14 / 134)$ and $26.1 \%(35 / 134)$, and in females were $6.4 \%(6 / 94)$ and $29.8 \%(28 / 94)$.

\subsection{Correlation between $H B s A g, H B e A g$ and $H B V D N A$ and $A L T$, Pathological Grade and Stage}

The Spearman correlation coefficients between HBsAg, HBeAg and HBV DNA and ALT, pathological grade and stage in the overall population and in the subpopulations with possible high and possible low HBV replication are summarized in Table 2. 

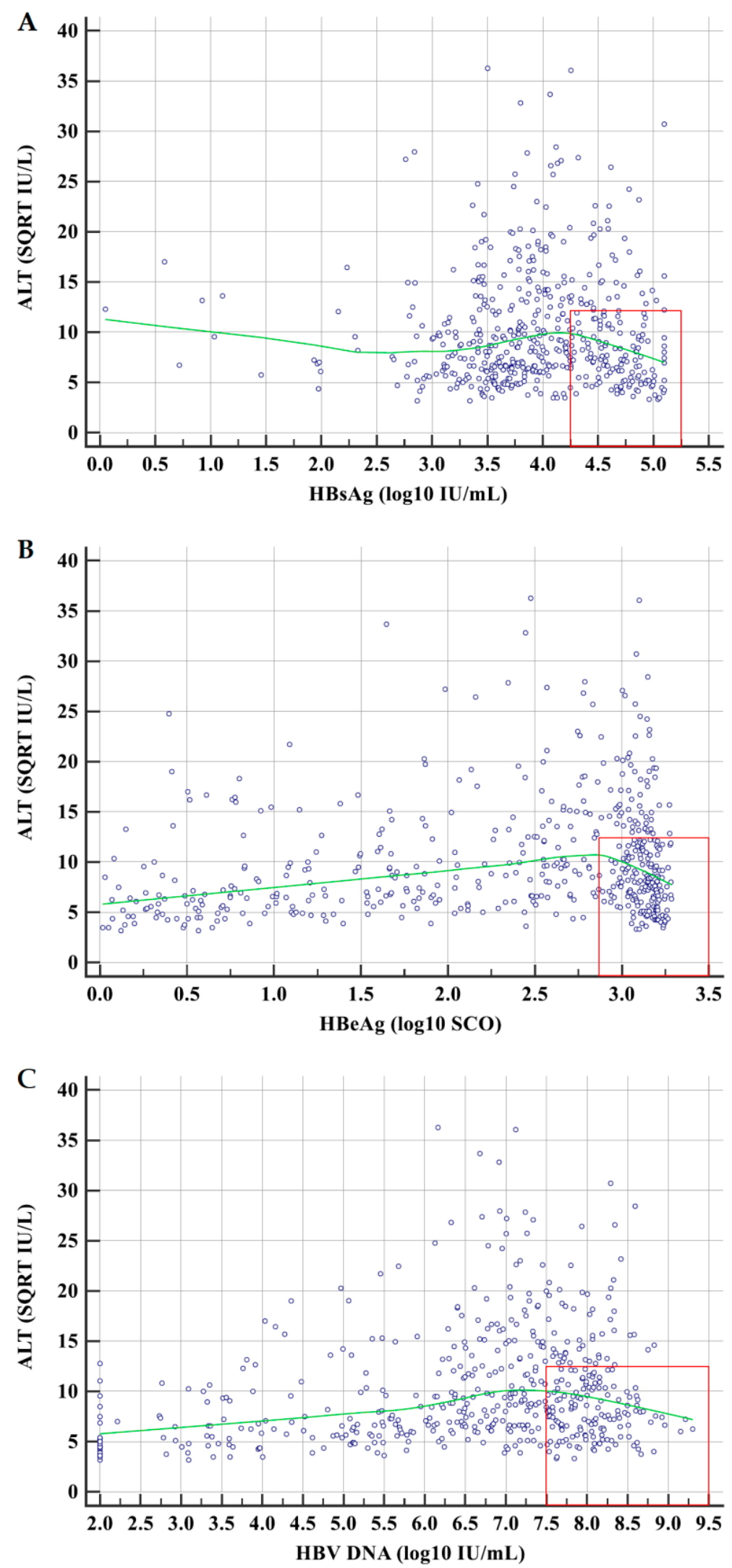

Figure 1. Scatter plots and LOESS regression curves between ALT and HBsAg (A), HBeAg (B) and HBV DNA (C). Abbreviations: ALT, alanine transferase; HBsAg, hepatitis B surface antigen; $\mathrm{HBeAg}$, hepatitis B e antigen; HBV DNA, hepatitis B virus DNA; SQRT, square root; $\log _{10}$, logarithm with base 10. The red boxes are used to delineate high levels of HBsAg, HBeAg and HBV DNA. 
Table 1. Demographic, laboratory and pathological characteristics of study population.

\begin{tabular}{|c|c|c|c|c|c|c|c|c|}
\hline \multirow{2}{*}{ Variable ${ }^{\#}$} & \multicolumn{2}{|r|}{ Overall } & \multicolumn{2}{|c|}{ Possible High HBV Replication } & \multicolumn{2}{|c|}{ Possible Low HBV Replication } & \multirow{2}{*}{$\chi^{2}{ }^{a} Z^{b *}$} & \multirow{2}{*}{$p^{*}$} \\
\hline & $\mathbf{n}$ & Summary Statistics & $\mathbf{n}$ & Summary Statistics & $\mathbf{n}$ & Summary Statistics & & \\
\hline Gender, male:female & 516 & $313: 203$ & 288 & $179: 109$ & 228 & $134: 94$ & $0.608^{\mathrm{a}}$ & 0.4354 \\
\hline Age, median (IQR) & 516 & $34.0(29.0-39.5)$ & 288 & $32.0(29.0-38.0)$ & 228 & $35.0(29.0-41.0)$ & $2.731^{b}$ & 0.0063 \\
\hline ALT, median (IQR) & 516 & $72.50(38.00-164.00)$ & 288 & $86.50(44.00-180.00)$ & 228 & $54.50(32.00-134.50)$ & $3.527^{b}$ & 0.0004 \\
\hline AST, median (IQR) & 516 & $46.00(28.00-87.00)$ & 288 & $49.00(30.00-92.50)$ & 228 & $42.50(27.00-73.00)$ & $1.946^{\mathrm{b}}$ & 0.0516 \\
\hline HBsAg, median (IQR) & 516 & $3.949(3.531-4.482)$ & 288 & $4.431(4.021-4.711)$ & 228 & $3.535(3.218-3.776)$ & $16.221^{\mathrm{b}}$ & $<0.0001$ \\
\hline HBeAg, median (IQR) & 516 & $2.758(1.618-3.113)$ & 288 & $3.100(2.980-3.175)$ & 228 & $1.585(0.725-2.310)$ & $17.572^{b}$ & $<0.0001$ \\
\hline HBV DNA, median (IQR) & 516 & $7.105(5.693-7.853)$ & 288 & 7.753 (7.264-8.152) & 228 & $5.707(3.932-6.598)$ & $16.762^{b}$ & $<0.0001$ \\
\hline Grade, G1:G2:G3:G4 & 516 & 268:190:58:0 & 288 & $171: 95: 22: 0$ & 228 & 97:95:36:0 & $17.066^{\mathrm{a}}$ & 0.0002 \\
\hline Stage, S0-1:S2:S3:S4 & 516 & 211:160:65:80 & 288 & 151:91:24:22 & 228 & $60: 69: 41: 58$ & $56.708^{\mathrm{a}}$ & $<0.0001$ \\
\hline
\end{tabular}

Abbreviations: ALT, alanine transferase; HBsAg, hepatitis B surface antigen; HBeAg, hepatitis B e antigen; HBV DNA, hepatitis B virus DNA; Grade, pathological grade; Stage, pathological stage; IQR, interquartile range. \# Units of measurement: Age, years; ALT, IU/L; AST, IU/L; HBsAg, $\log _{10} \mathrm{IU} / \mathrm{mL} ; \mathrm{HBeAg}, \log _{10} \mathrm{SCO} ; \mathrm{HBV} \mathrm{DNA}, \log _{10} \mathrm{IU} / \mathrm{mL}$. * Possible high HBV replication versus Possible low HBV replication: ${ }^{a}$ Chi-squared test; ${ }^{b}$ Mann-WhitneyU test.

\subsection{Performance of HBsAg, HBeAg and HBV DNA in Predicting Significant Hepatitis Activity}

In the overall population, the AUCs of HBsAg, HBeAg and HBV DNA for predicting "ALT $\geq 20 \mathrm{IU} / \mathrm{L}$ or Grade $>$ G1 or Stage $>$ S1" were 0.660, 0.573 and 0.538 , for predicting "ALT $\geq 30 \mathrm{IU} / \mathrm{L}$ or Grade $>$ G1 or Stage $>$ S1" were $0.682,0.600$ and 0.504 , and for predicting "ALT $\geq 40 \mathrm{IU} / \mathrm{L}$ or Grade $>$ G1 or Stage $>$ S1" were 0.654, 0.580 and 0.522; among them, the AUC of HBsAg for predicting "ALT $\geq 20 \mathrm{IU} / \mathrm{L}$ or Grade $>$ G1 or Stage > S1" was significantly greater than that of $\mathrm{HBV}$ DNA $(Z=2.143, p=0.0321)$, the AUC of HBsAg and HBeAgfor predicting "ALT $\geq 30 \mathrm{IU} / \mathrm{L}$ or Grade $>$ G1 or Stage $>$ S1" was significantly greater than that of HBV DNA $(Z=4.588, p<0.0001$ and $Z=2.348, p=0.0189)$, and the AUC of HBsAg for predicting "ALT $\geq 40 \mathrm{IU} / \mathrm{L}$ or Grade $>$ G1 or Stage $>$ S1" was significantly greater than that of HBeAg and HBV DNA $(Z=2.013, p=0.0441$ and $Z=4.280, p<0.0001)$.

Table 2. Correlation between HBsAg, HBeAg and HBV DNA and ALT, liver pathological grade and stage.

\begin{tabular}{|c|c|c|c|c|c|c|c|c|c|c|c|c|}
\hline \multicolumn{2}{|c|}{ Correlated Variables } & \multicolumn{3}{|c|}{ Overall } & \multicolumn{3}{|c|}{ Possible High HBV Replication } & \multicolumn{3}{|c|}{ Possible Low HBV Replication } & \multirow{2}{*}{$Z^{*}$} & \multirow{2}{*}{$p^{*}$} \\
\hline Variable y & Variable $x$ & $\mathbf{n}$ & $r_{s}$ & $p$ & $\mathbf{n}$ & $r_{s}$ & $p$ & $\mathbf{n}$ & $r_{s}$ & $p$ & & \\
\hline ALT & HBsAg & 516 & 0.004 & 0.9232 & 288 & $-0.303^{a}$ & $<0.0001$ & 228 & $0.029 \mathrm{~g}, \mathrm{~h}$ & 0.6655 & 3.833 & 0.0001 \\
\hline ALT & HBeAg & 516 & 0.131 & 0.0030 & 288 & $-0.268^{b}$ & $<0.0001$ & 228 & $0.427 \mathrm{~g}$ & $<0.0001$ & 8.196 & $<0.0001$ \\
\hline ALT & HBV DNA & 516 & 0.211 & $<0.0001$ & 288 & $-0.109^{a, b}$ & 0.0639 & 228 & $0.530^{\mathrm{h}}$ & $<0.0001$ & 7.845 & $<0.0001$ \\
\hline Grade & HBsAg & 516 & -0.291 & $<0.0001$ & 288 & $-0.351^{\mathrm{c}}$ & $<0.0001$ & 228 & $-0.087^{i, j}$ & 0.1898 & 3.133 & 0.0017 \\
\hline Grade & $\mathrm{HBeAg}$ & 516 & -0.250 & $<0.0001$ & 288 & $-0.375^{\mathrm{d}}$ & $<0.0001$ & 228 & $0.099^{\mathrm{i}}$ & 0.1348 & 5.534 & $<0.0001$ \\
\hline Grade & HBV DNA & 516 & -0.104 & 0.0182 & 288 & $-0.102^{c, d}$ & 0.0837 & 228 & $0.207^{j}$ & 0.0017 & 3.503 & 0.0005 \\
\hline Stage & HBsAg & 516 & -0.384 & $<0.0001$ & 288 & $-0.303^{\mathrm{e}}$ & $<0.0001$ & 228 & $-0.135^{\mathrm{k}}$ & 0.0414 & 1.985 & 0.0472 \\
\hline Stage & HBeAg & 516 & -0.373 & $<0.0001$ & 288 & $-0.361^{f}$ & $<0.0001$ & 228 & 0.019 & 0.7714 & 4.452 & $<0.0001$ \\
\hline Stage & HBV DNA & 516 & -0.241 & $<0.0001$ & 288 & -0.089 e,f & 0.1311 & 228 & $0.062^{\mathrm{k}}$ & 0.3542 & 1.697 & 0.0897 \\
\hline
\end{tabular}

Abbreviations: ALT, alanine transferase; HBsAg, hepatitis B surface antigen; HBeAg, hepatitis B e antigen; HBV DNA, hepatitis B virus DNA; Grade, pathological grade; Stage, pathological stage. * Possible high HBV replication versus Possible low HBV replication: Fisher $Z$ test. ${ }^{a-k}$ Fisher $Z$ test: ${ }^{\mathrm{a}}, Z=2.428, p=0.0152{ }^{\mathrm{b}}, \mathrm{b}=1.973, p=0.0485 ;{ }^{\mathrm{c}}, Z=3.154, p=0.0016{ }^{\mathrm{d}}, \mathrm{C}=3.484, p=0.0005 ;{ }^{\mathrm{e}}, \mathrm{Z}=2.669, p=0.0076$; ${ }^{\mathrm{f}}, \mathrm{Z}=3.448, p=0.0006 ;{ }^{\mathrm{g}}, \mathrm{Z}=4.531, p<0.0001{ }^{\mathrm{h}}, \mathrm{Z}=5.952, p<0.0001{ }^{\mathrm{i}}, \mathrm{Z}=1.979, p=0.0479 ;{ }^{\mathrm{j}}, \mathrm{Z}=3.153, p=0.0016{ }^{\mathrm{k}}, \mathrm{Z}=2.099, p=0.0358$.

In the overall population, the AUCs of HBsAg, HBeAg and HBV DNA for predicting "ALT $\geq 20 \mathrm{IU} / \mathrm{L}$ " were $0.551,0.569$ and 0.661 , for predicting "ALT $\geq 30 \mathrm{IU} / \mathrm{L}$ " were 0.533 , 0.575 and 0.647 , respectively, and for predicting "ALT $\geq 40 \mathrm{IU} / \mathrm{L}$ " were $0.507,0.592$ and 0.635; among them, the AUC of HBsAg and HBeAg for predicting "ALT $\geq 20 \mathrm{IU} / \mathrm{L}$ " was significantly less than that of HBV DNA $(Z=2.529, p=0.0114$ and $Z=1.997, p=0.0459)$, the AUC of HBsAg and HBeAg for predicting "ALT $\geq 30 \mathrm{IU} / \mathrm{L}$ " was significantly less than that of HBV DNA $(Z=4.092, p<0.0001$ and $Z=2.347, p=0.0189)$, and the AUC of HBsAg for predicting "ALT $\geq 40 \mathrm{IU} / \mathrm{L}$ " was significantly less than that of HBeAg and HBV DNA $(Z=3.119, p=0.0018$ and $Z=5.385, p<0.0001)$.

In the subpopulations with possible high and possible low $\mathrm{HBV}$ replication, the ROC curves and AUCs of HBsAg, HBeAg and HBV DNA for predicting "ALT $\geq 20 \mathrm{IU} / \mathrm{L}$ or 
Grade $>$ G1 or Stage $>$ S1" and "ALT $\geq 20 \mathrm{IU} / \mathrm{L}$ ", "ALT $\geq 30 \mathrm{IU} / \mathrm{L}$ or Grade $>$ G1 or Stage $>$ S1" and "ALT $\geq 30 \mathrm{IU} / \mathrm{L}$ ", and "ALT $\geq 40 \mathrm{IU} / \mathrm{L}$ or Grade $>$ G1 or Stage $>$ S1" and "ALT $\geq 40 \mathrm{IU} / \mathrm{L}$ " are illustrated in Figure 2 and summarized in Table 3.
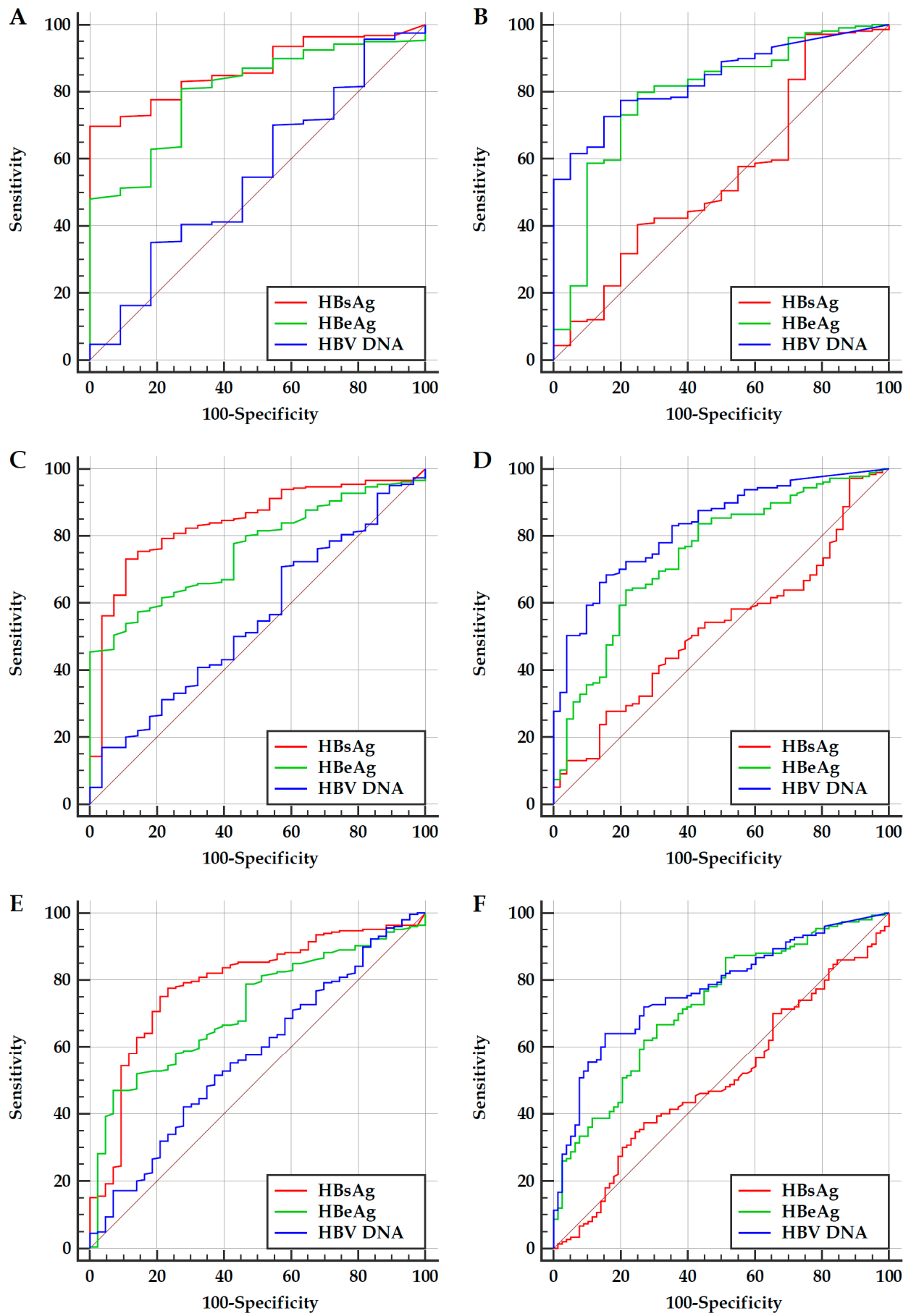

Figure 2. The ROC curves of HBsAg, HBeAg and HBV DNA for predicting significant hepatitis activity in subpopulation with possible high and low HBV replication. Abbreviations: ROC, receiver operating characteristic; HBsAg, hepatitis B surface antigen; HBeAg, hepatitis B e antigen; HBV DNA, hepatitis B virus DNA; ALT, alanine transferase. (A,C,E): Predicting "ALT $\geq 20$ IU/L or Grade $>$ G1 or Stage $>$ S1" (A), "ALT $\geq 30 \mathrm{IU} / \mathrm{L}$ or Grade $>$ G1 or Stage $>$ S1" $($ C) and "ALT $\geq 40$ IU $/ \mathrm{L}$ or Grade $>$ G1 or Stage $>$ S1" $($ E) in patients with possible high HBV replication; $(\mathbf{B}, \mathbf{D}, \mathbf{F})$ : Predicting "ALT $\geq 20 \mathrm{IU} / \mathrm{L}$ " (B), "ALT $\geq 30 \mathrm{IU} / \mathrm{L}$ " (D) and "ALT $\geq 40 \mathrm{IU} / \mathrm{L}$ " (F) in patients with possible low HBV replication. 
Table 3. Performance of HBsAg, HBeAg and HBV DNA in predicting significant hepatitis activity.

\begin{tabular}{|c|c|c|c|c|c|c|c|c|c|c|c|}
\hline \multicolumn{12}{|c|}{ Predicting "ALT $\geq 20$ IU/L or Grade > G1 or Stage > S1" in Subpopulation with Possible High HBV Replication } \\
\hline Variable & AUC & SE & Z & $p$ & Cutoff * & Sen $(\%)$ & Spe $(\%)$ & pLR & nLR & pPV (\%) & nPV (\%) \\
\hline \multirow[t]{2}{*}{ HBsAg } & $0.868^{a}$ & 0.0332 & 11.087 & $<0.0001$ & $\leq 4.615^{\mathrm{I}}$ & 69.68 & 100.00 & $+\infty$ & 0.30 & 100.0 & 11.6 \\
\hline & & & & & $\leq 4.699$ II & 75.81 & 81.82 & 4.17 & 0.30 & 99.1 & 11.8 \\
\hline \multirow[t]{2}{*}{ HBeAg } & $0.802^{b}$ & 0.0530 & 5.695 & $<0.0001$ & $\leq 3.187^{\mathrm{I}}$ & 80.87 & 72.73 & 2.97 & 0.26 & 98.7 & 13.1 \\
\hline & & & & & $\leq 3.154 \mathrm{II}$ & 70.40 & 72.73 & 2.58 & 0.41 & 98.5 & 8.9 \\
\hline HBV DNA & $0.553^{a, b}$ & 0.0903 & 0.590 & 0.5549 & & & & & & & \\
\hline \multicolumn{12}{|c|}{ Predicting "ALT $\geq 30$ IU/L or Grade > G1 or Stage > S1" in Subpopulation with Possible High HBV Replication } \\
\hline Variable & AUC & SE & $Z$ & $p$ & Cutoff * & Sen $(\%)$ & Spe (\%) & pLR & nLR & pPV (\%) & nPV (\%) \\
\hline \multirow[t]{2}{*}{ HBsAg } & $0.839^{c}$ & 0.0355 & 9.540 & $<0.0001$ & $\leq 4.615^{\mathrm{I}}$ & 73.08 & 89.29 & 6.82 & 0.30 & 98.4 & 26.3 \\
\hline & & & & & $\leq 4.699$ II & 79.23 & 78.57 & 3.70 & 0.26 & 97.2 & 28.9 \\
\hline \multirow[t]{2}{*}{ HBeAg } & $0.758^{d}$ & 0.0363 & 7.099 & $<0.0001$ & $\leq 3.062^{\mathrm{I}}$ & 45.38 & 100.00 & $+\infty$ & 0.55 & 100.0 & 16.5 \\
\hline & & & & & $\leq 3.154$ II & 71.54 & 57.14 & 1.67 & 0.50 & 93.9 & 17.8 \\
\hline HBV DNA & $0.550^{\mathrm{c}, \mathrm{d}}$ & 0.0551 & 0.911 & 0.3621 & & & & & & & \\
\hline \multicolumn{12}{|c|}{ Predicting "ALT $\geq 40$ IU/L or Grade $>$ G1 or Stage $>$ S1" in Subpopulation with Possible High HBV Replication } \\
\hline Variable & AUC & SE & $Z$ & $p$ & Cutoff * & Sen $(\%)$ & Spe (\%) & pLR & nLR & pPV (\%) & nPV (\%) \\
\hline \multirow[t]{2}{*}{ HBsAg } & $0.789^{\mathrm{e}}$ & 0.0372 & 7.766 & $<0.0001$ & $\leq 4.663^{\text {I }}$ & 77.55 & 76.74 & 3.33 & 0.29 & 95.0 & 37.5 \\
\hline & & & & & $\leq 4.699$ II & 80.82 & 67.44 & 2.48 & 0.28 & 93.4 & 38.2 \\
\hline \multirow[t]{2}{*}{ HBeAg } & $0.713^{f}$ & 0.0376 & 5.684 & $<0.0001$ & $\leq 3.062^{\mathrm{I}}$ & 46.94 & 93.02 & 6.73 & 0.57 & 97.5 & 23.5 \\
\hline & & & & & $\leq 3.154 \mathrm{II}$ & 72.65 & 53.49 & 1.56 & 0.51 & 89.9 & 25.6 \\
\hline HBV DNA & $0.574 \mathrm{e}, \mathrm{f}$ & 0.0470 & 1.571 & 0.1162 & & & & & & & \\
\hline \multicolumn{12}{|c|}{ Predicting "ALT $\geq 20$ IU/L" in Subpopulation with Possible Low HBV Replication } \\
\hline Variable & AUC & SE & $Z$ & $p$ & Cutoff * & Sen $(\%)$ & Spe (\%) & pLR & nLR & pPV (\%) & nPV (\%) \\
\hline HBsAg & $0.549 \mathrm{~g}, \mathrm{~h}$ & 0.0710 & 0.671 & 0.5024 & & & & & & & \\
\hline \multirow[t]{2}{*}{ HBeAg } & $0.789 \mathrm{~g}$ & 0.0562 & 5.030 & $<0.0001$ & $>0.718^{\mathrm{I}}$ & 79.81 & 75.00 & 3.19 & 0.27 & 97.1 & 26.3 \\
\hline & & & & & $>0.861^{\mathrm{II}}$ & 73.08 & 80.00 & 3.65 & 0.34 & 97.4 & 22.2 \\
\hline \multirow[t]{2}{*}{ HBV DNA } & $0.838^{\mathrm{h}}$ & 0.0341 & 9.823 & $<0.0001$ & $>4.756^{\mathrm{I}}$ & 72.60 & 85.00 & 4.84 & 0.32 & 98.1 & 23.0 \\
\hline & & & & & $>4.362 \mathrm{II}$ & 74.52 & 80.00 & 3.73 & 0.32 & 97.5 & 23.2 \\
\hline \multicolumn{12}{|c|}{ Predicting "ALT $\geq 30$ IU/L" in Subpopulation with Possible Low HBV Replication } \\
\hline Variable & AUC & SE & $Z$ & $p$ & Cutoff * & Sen $(\%)$ & Spe (\%) & pLR & nLR & pPV (\%) & nPV (\%) \\
\hline HBsAg & $0.526^{i, j}$ & 0.0437 & 0.582 & 0.5609 & & & & & & & \\
\hline \multirow[t]{2}{*}{ HBeAg } & $0.745^{\mathrm{i}, \mathrm{k}}$ & 0.0391 & 6.244 & $<0.0001$ & $>1.398^{\mathrm{I}}$ & 63.84 & 78.43 & 2.96 & 0.46 & 91.1 & 38.5 \\
\hline & & & & & $>0.861 \mathrm{II}$ & 76.84 & 60.78 & 1.96 & 0.38 & 87.2 & 43.1 \\
\hline \multirow[t]{2}{*}{ HBV DNA } & $0.827^{\mathrm{j}, \mathrm{k}}$ & 0.0300 & 10.858 & $<0.0001$ & $>5.418^{\mathrm{I}}$ & 68.36 & 84.31 & 4.36 & 0.38 & 93.8 & 43.4 \\
\hline & & & & & $>4.362$ II & 79.66 & 64.71 & 2.26 & 0.31 & 88.7 & 47.8 \\
\hline \multicolumn{12}{|c|}{ Predicting "ALT $\geq 40$ IU/L" in Subpopulation with Possible Low HBV Replication } \\
\hline Variable & AUC & SE & $Z$ & $p$ & Cutoff * & Sen $(\%)$ & Spe $(\%)$ & pLR & nLR & pPV (\%) & nPV (\%) \\
\hline HBsAg & $0.502^{1, m}$ & 0.0399 & 0.050 & 0.9600 & & & & & & & \\
\hline \multirow[t]{2}{*}{ HBeAg } & $0.724^{\mathrm{I}}$ & 0.0347 & 6.441 & $<0.0001$ & $>1.398^{\mathrm{I}}$ & 66.67 & 69.23 & 2.17 & 0.48 & 80.6 & 51.9 \\
\hline & & & & & $>0.861^{\mathrm{II}}$ & 78.67 & 51.28 & 1.61 & 0.42 & 75.6 & 55.6 \\
\hline \multirow[t]{2}{*}{ HBV DNA } & $0.770^{\mathrm{m}}$ & 0.0314 & 8.592 & $<0.0001$ & $>5.860^{\mathrm{I}}$ & 64.00 & 84.62 & 4.16 & 0.43 & 88.9 & 55.0 \\
\hline & & & & & $>4.362^{\mathrm{II}}$ & 80.00 & 50.00 & 1.60 & 0.40 & 75.5 & 56.5 \\
\hline
\end{tabular}

Abbreviations: ROC, receiver operating characteristic; AUC, area under ROC curve; SE, standard error; HBsAg, hepatitis B surface antigen; HBeAg, hepatitis B e antigen; HBV DNA, hepatitis B virus DNA; ALT, alanine transferase; Grade, pathological grade; Stage, pathological stage; Sen, sensitivity; Spe, specificity; pLR, positive likelihood ratio; nLR, negative likelihood ratio; pPV, positive predictive value; $\mathrm{nPV}$, negative predictive value.* Units of measurement: $\mathrm{HBs} A g, \log _{10} \mathrm{IU} / \mathrm{mL} ; \mathrm{HBeAg}, \log _{10}$ SCO; HBV DNA, $\log _{10} \mathrm{IU} / \mathrm{mL}$. I Optimal cutoff; II Practical cutoff. ${ }^{a-1}$ Dependent sample Hanley and McNeil nonparametric test: ${ }^{\mathrm{a}}, Z=3.779, p=0.0002 ;{ }^{\mathrm{b}}, Z=2.697, p=0.0070 ;{ }^{\mathrm{c}}, Z=5.131$, $p<0.0001 ;{ }^{\mathrm{d}}, Z=3.479, p=0.0005 ;{ }^{\mathrm{e}}, \mathrm{Z}=4.385, p<0.0001 ;{ }^{\mathrm{f}}, \mathrm{Z}=2.557, p=0.0106 ; \mathrm{g}, Z=2.705, p=0.0068 ;{ }^{\mathrm{h}}, Z=3.917, p=0.0001 ;{ }^{\mathrm{i}}, Z=3.898$, $p=0.0001 ;{ }^{j}, Z=6.468, p<0.0001 ;{ }^{k}, Z=2.128, p=0.0333 ;{ }^{1}, Z=4.310, p<0.0001 ;{ }^{m}, Z=6.010, p<0.0001$. 
Based on the Youden index, an optimal cutoff was determined. With reference to the minimum difference between the specificity of $\mathrm{HBsAg}$ and $\mathrm{HBeAg}$ for predicting "ALT $\geq 20 \mathrm{IU} / \mathrm{L}$ or Grade $>$ G1 or Stage $>$ S1" and the sensitivity of HBsAg and HBeAg for predicting "ALT $\geq 40 \mathrm{IU} / \mathrm{L}$ or Grade $>$ G1 or Stage $>$ S1" in the subpopulation with possible high HBV replication, and between the specificity of HBV DNA and HBeAg for predicting "ALT $\geq 20 \mathrm{IU} / \mathrm{L}$ " and the sensitivity of HBV DNA and HBeAg for predicting "ALT $\geq 40 \mathrm{IU} / \mathrm{L}$ " in the subpopulation with possible low HBV replication, a practical cutoff that was easy to remember was chosen. The optimal cutoffs and practical cutoffs with corresponding diagnostic parameters are summarized in Table 3.

\subsection{Reliability of HBsAg, HBeAg and HBV DNA in Predicting Liver Pathological States}

The proportions of liver pathological grades and stages in patients with HBsAg > $4.699 \log _{10} \mathrm{IU} / \mathrm{mL}$ or HBeAg $>3.154 \log _{10} \mathrm{SCO}$ or HBV DNA $\leq 4.362 \log _{10} \mathrm{IU} / \mathrm{mL}$ or HBeAg $\leq 0.861 \log _{10}$ SCO alone and in combination with ALT $<20 \mathrm{IU} / \mathrm{L},<30 \mathrm{IU} / \mathrm{L}$ or $<40 \mathrm{IU} / \mathrm{L}$ are summarized in Table 4.

Table 4. Reliability of HBsAg, HBeAg or HBV DNA alone and in combination with ALT in predicting pathological states.

\begin{tabular}{|c|c|c|c|c|c|c|c|c|}
\hline \multirow[t]{2}{*}{ Variable ${ }^{\#}$} & \multirow[t]{2}{*}{$\mathbf{n}$} & \multicolumn{3}{|c|}{ Proportion of Pathological Grades } & \multicolumn{4}{|c|}{ Proportion of Pathological Stages } \\
\hline & & G1, \% (n) & $\mathrm{G} 2, \%(\mathrm{n})$ & $\mathrm{G} 3, \%(\mathrm{n})$ & S0-1, \% (n) & $\mathrm{S} 2, \%(\mathrm{n})$ & $\mathrm{S} 3, \%(\mathrm{n})$ & $\mathrm{S} 4, \%(\mathrm{n})$ \\
\hline ALT $<20$ & 36 & $83.3(30)$ & $13.9(5)$ & $2.8(1)$ & $55.6(20)$ & $33.3(12)$ & $5.6(2)$ & $5.6(2)$ \\
\hline ALT $<30$ & 91 & $76.9(70)$ & $19.8(18)$ & $3.3(3)$ & $52.7(48)$ & $29.7(27)$ & $7.7(7)$ & $9.9(9)$ \\
\hline ALT $<40$ & 138 & $73.9(102)$ & $20.3(28)$ & $5.8(8)$ & $52.9(73)$ & $26.1(36)$ & $9.4(13)$ & $11.6(16)$ \\
\hline HBsAg $>4.699$ & 77 & $84.4(65)$ & $14.3(11)$ & $1.3(1)$ & $68.8(53)$ & $29.9(23)$ & $1.3(1)$ & $0.0(0)$ \\
\hline HBsAg $>4.699$ and ALT $<20$ & 10 & $100.0(10)$ & $0.0(0)$ & $0.0(0)$ & $90.0(9)$ & $10.0(1)$ & $0.0(0)$ & $0.0(0)$ \\
\hline HBsAg $>4.699$ and ALT $<30$ & 27 & $96.3(26)$ & $3.7(1)$ & $0.0(0)$ & $81.5(22)$ & $18.5(5)$ & $0.0(0)$ & $0.0(0)$ \\
\hline HBsAg $>4.699$ and ALT $<40$ & 35 & $97.1(34)$ & $2.9(1)$ & $0.0(0)$ & $82.9(29)$ & $17.1(6)$ & $0.0(0)$ & $0.0(0)$ \\
\hline $\mathrm{HBeAg}>3.154$ & 90 & $75.6(68)$ & $22.2(20)$ & $2.2(2)$ & $68.9(62)$ & $25.6(23)$ & $2.2(2)$ & $3.3(3)$ \\
\hline HBeAg $>3.154$ and ALT $<20$ & 10 & $90.0(9)$ & $10.0(1)$ & $0.0(0)$ & $90.0(9)$ & $10.0(1)$ & $0.0(0)$ & $0.0(0)$ \\
\hline HBeAg $>3.154$ and ALT $<30$ & 22 & $95.5(21)$ & $4.5(1)$ & $0.0(0)$ & $77.3(17)$ & $22.7(5)$ & $0.0(0)$ & $0.0(0)$ \\
\hline HBeAg $>3.154$ and ALT $<40$ & 29 & $96.6(28)$ & $3.4(1)$ & $0.0(0)$ & $82.8(24)$ & $17.2(5)$ & $0.0(0)$ & $0.0(0)$ \\
\hline HBV DNA $\leq 4.362$ & 73 & $54.8(40)$ & $32.9(24)$ & $12.3(9)$ & $34.2(25)$ & $27.4(20)$ & $11.0(8)$ & $27.4(20)$ \\
\hline $\mathrm{HBV}$ DNA $\leq 4.362$ and ALT $<20$ & 16 & $75.0(12)$ & $18.8(3)$ & $6.2(1)$ & $31.2(5)$ & $43.7(7)$ & $12.5(2)$ & $12.5(2)$ \\
\hline HBV DNA $\leq 4.362$ and ALT $<30$ & 33 & $63.6(21)$ & $30.3(10)$ & $6.1(2)$ & $36.4(12)$ & $36.4(12)$ & $9.1(3)$ & $18.2(6)$ \\
\hline $\mathrm{HBV}$ DNA $\leq 4.362$ and ALT $<40$ & 39 & $61.5(24)$ & $28.2(11)$ & $10.3(4)$ & $35.9(14)$ & $33.3(13)$ & $10.3(4)$ & $20.5(8)$ \\
\hline $\mathrm{HBeAg} \leq 0.861$ & 76 & $47.4(36)$ & $35.5(27)$ & $17.1(13)$ & $30.3(23)$ & $31.6(24)$ & $13.2(10)$ & $25.0(19)$ \\
\hline $\mathrm{HBeAg} \leq 0.861$ and ALT $<20$ & 16 & $81.2(13)$ & $12.5(2)$ & $6.2(1)$ & $37.5(6)$ & $43.7(7)$ & $6.2(1)$ & $12.5(2)$ \\
\hline $\mathrm{HBeAg} \leq 0.861$ and ALT $<30$ & 31 & $67.7(21)$ & $25.8(8)$ & $6.5(2)$ & $38.7(12)$ & $32.3(10)$ & $12.9(4)$ & $16.1(5)$ \\
\hline $\mathrm{HBeAg} \leq 0.861$ and ALT $<40$ & 41 & $65.9(27)$ & $24.4(10)$ & $9.8(4)$ & $39.0(16)$ & 31.7 (13) & $12.2(5)$ & $17.1(7)$ \\
\hline
\end{tabular}

Abbreviations: ALT, alanine transferase; HBsAg, hepatitis B surface antigen; $\mathrm{HBeAg}$, hepatitis B e antigen; HBV DNA, hepatitis B virus DNA. \# Units of measurement: ALT, IU/L; HBsAg, $\log _{10} \mathrm{IU} / \mathrm{mL} ; \mathrm{HBeAg}, \log _{10} \mathrm{SCO} ; \mathrm{HBV}$ DNA, $\log _{10} \mathrm{IU} / \mathrm{mL}$.

\section{Discussion}

In this study, based on a subpopulation with possible high and possible low HBV replication, we explored the role of HBsAg, HBeAg and HBV DNA in the persistence and onset of HBeAg-positive chronic HBV infection, and with reference to the criteria of "the preset ULNs for ALT" and "Grade > G1 or Stage > S1", we evaluated the performance of HBsAg, HBeAg and HBV DNA in predicting significant hepatitis activity of HBeAgpositive chronic $\mathrm{HBV}$ infection. We also chose the practical cutoffs of $\mathrm{HBs} \mathrm{Ag}$ and $\mathrm{HBeAg}$ in predicting significant hepatitis activity in a subpopulation with possible high HBV replication and of HBV DNA and HBeAg in predicting significant hepatitis activity in a subpopulation with possible low $\mathrm{HBV}$ replication, and evaluated the reliability of $\mathrm{HBsAg}$, HBeAg or HBV DNA alone and in combination with ALT in predicting liver pathological grades and stages.

So far, the nomenclature of four natural history phases of chronic HBV infection has not been fully unified [2-4]. Conventionally, HBeAg-positive non-significant hepatitis activity is titled "immune tolerance", which is still adopted by the Asian Pacific Association for the 
Study of the Liver (APASL) guidelines (2015) and the American Association for the Study of Liver Diseases (AASLD) guidelines (2018) [2-4]. In recent years, the naming of "immune tolerance" has been challenged [24-28]. In fact, most of the patients in the "immune tolerance" phase have slight liver necro-inflammation, with no or slight liver fibrosis progression [24-28]. All patients enrolled in this study, including "normal" ALT with "high levels" of HBV DNA, have varying degrees of liver necro-inflammation and fibrosis. Thereby, the European Association for the Study of the Liver (EASL) guidelines (2017) have denominated "immune tolerance" as "HBeAg-positive chronic HBV infection" [3]. However, "immune tolerance" remains an important immunological mechanism for the persistence of chronic HBV infection [29], and "HBeAg-positive chronic HBV infection" does not deny the existence of the "immune tolerance" mechanism [3].

The virological mechanisms of the persistence and onset of chronic HBV infection have not been thoroughly elucidated [29-31]. The scatter plots between ALT and HBsAg, HBeAg and HBV DNA of this study showed that the proportions of ALT $\geq 40 \mathrm{IU} / \mathrm{L}$ in patients with high levels of HBsAg, HBeAg and HBV DNA were all greater than $70 \%$, which suggested that biochemically significant hepatitis activity was common in patients with high HBV replication. The correlation analyses between ALT and HBsAg, HBeAg and HBV DNA of this study also showed that ALT in the subpopulation with possible high $\mathrm{HBV}$ replication was significantly negatively correlated with $\mathrm{HBsAg}$ and $\mathrm{HBeAg}$, but not with HBV DNA, and in the subpopulation with possible low HBV replication was significantly positively correlated with HBV DNA and $\mathrm{HBeAg}$, but not with $\mathrm{HBsAg}$. These suggested that medium to high levels of $\mathrm{HBs} A g$ and $\mathrm{HBeAg}$, by inhibiting the immune response against HBV [29-31], may induce the persistence of chronic HBV infection, while low to medium levels of HBV DNA and HBeAg, by activating the immune response against $\mathrm{HBV}$, may cause the onset of chronic HBV infection.

The results of this study also support the inferences on the virological pathogenesis of chronic HBV infection based on experimental studies: high and medium-low levels of serum HBsAg, by inducing immune exhaustion and immune ignorance [32-34], may play a role in maintaining the persistence of chronic HBV infection, while high and medium-low levels of serum $\mathrm{HBeAg}$, by inducing immune exhaustion and immune activation, may play a role in maintaining the persistence and in causing the onset of chronic HBV infection [35]. The levels of serum HBV DNA may reflect the levels of transcription and translation of HBV genes in liver cells. The high and medium-low levels of expression of intrahepatic $\mathrm{HBcAg}$ and HBeAg and medium-low levels of expression of serum HBeAg may all be the main targets of the host immune attack. The facultative effects of serum HBeAg-induced immune exhaustion and immune activation may be related to its successful short-sighted evolution [35].

To date, there is no consensus on ULNs for ALT, which can be used to predict significant hepatitis activity in chronic HBV infection [2-4]. The APASL guidelines (2015) and the EASL guidelines (2017) recommend the use of traditional normal references with $\mathrm{ALT}<40 \mathrm{IU} / \mathrm{L}$ [2,3], and the AASLD guidelines (2018) recommend the use of novel normal references with ALT $\leq 35 \mathrm{IU} / \mathrm{L}$ for males and $\leq 25 \mathrm{IU} / \mathrm{L}$ for females [4]. However, the liver histological criteria based on Scheuer, Ludwig, Ishak and METAVIR scoring systems, which are widely used at present, have a high consistency in delimiting the pathological grades and stages of chronic hepatitis [36]. In this study, we preset three levels of ULNs with ALT $\geq 20 \mathrm{IU} / \mathrm{L}, \geq 30 \mathrm{IU} / \mathrm{L}$ and $\geq 40 \mathrm{IU} / \mathrm{L}$ as criteria for biochemically significant hepatitis activity, and used "Grade $>$ G1 or Stage $>$ S1" of the Scheuer scoring system as criteria for pathologically significant hepatitis activity.

In patients with $\mathrm{HBeAg}$-positive chronic HBV infection, non-significant hepatitis activity is not only related to high levels but also low levels of HBV replication. Among them, non-significant hepatitis activity related to high levels of HBV replication belongs to "persistent inactivity" of the "immune tolerance" phase, which is manifested as nonsignificant serum biochemical abnormalities and non-significant liver histological changes, while non-significant hepatitis activity related to low levels of HBV replication belongs 
to "transient inactivity" of the "immune activation" phase, which is manifested as nonsignificant serum biochemical abnormalities and unconfined liver histological changes (See Appendix A.8). Therefore, in this study, significant hepatitis activity of the subpopulation with possible high HBV replication was defined as "ALT $\geq$ ULNs or Grade > G1 or Stage $>$ S1", and with possible low HBV replication was defined as "ALT $\geq$ ULNs". The ROC curve analyses of this study showed that, in the overall population, the AUCs of HBsAg, HBeAg and HBV DNA for predicting significant hepatitis activity were all less than 0.70; among them, the AUCs of HBsAg for predicting "ALT $\geq$ ULNs or Grade > G1 or Stage $>$ S1" were all greater and all less than those of HBV DNA. The ROC curve analyses of this study also showed that, in the subpopulation with possible high HBV replication, the AUCs of HBsAg and HBeAg for predicting "ALT $\geq$ ULNs or Grade > G1 or Stage > S1" were all greater than 0.75 and 0.70 , which were all significantly greater than those of $\mathrm{HBV}$ DNA as those were not valuable for predicting "ALT $\geq$ ULNs or pathological grade $>$ G1 or stage > S1"; in contrast, in the subpopulation with possible low HBV replication, the AUCs of HBV DNA and HBeAg for predicting "ALT $\geq$ ULNs" were all greater than 0.75 and 0.70, which were all significantly greater than those of HBsAg as those were not valuable for predicting "ALT $\geq$ ULNs". These suggested that, in patients with HBeAg-positive chronic HBV infection, HBsAg and HBV DNA are a reliable indicator in predicting the first significant hepatitis activity or "immune activation" and second significant hepatitis activity or "immune reactivation", and HBeAg is the collaborative indicator of HBsAg and HBV DNA in predicting the first and second significant hepatitis activity; the delimitation of the subpopulations with possible high and possible low HBV replication has important value for reasonably and effectively evaluating the performance of $\mathrm{HBsAg}, \mathrm{HBeAg}$ and HBV DNA for predicting significant hepatitis activity.

In this study, we chose the practical cutoffs of HBsAg and HBeAg and of HBV DNA and HBeAg, which were convenient for clinical application, for predicting significant hepatitis activity in subpopulations with possible high and low HBV replication. Based on information of this study population, in patients with ALT $\geq 20 \mathrm{IU} / \mathrm{L}, \geq 30 \mathrm{IU} / \mathrm{L}$ and $\geq 40 \mathrm{IU} / \mathrm{L}$, the proportions of liver pathological stage $>\mathrm{S} 1$ and $>\mathrm{S} 2$ were $44.4 \%$ and $11.2 \%$, $47.3 \%$ and $17.6 \%$ and $47.1 \%$ and $21.0 \%$. In patients with $\mathrm{HBsAg}>4.699 \log 10 \mathrm{IU} / \mathrm{mL}$, the proportions of liver pathological stage $>$ S1 and > S2 were 31.2\% and 1.3\%, and in combination with $\mathrm{ALT} \geq 40 \mathrm{IU} / \mathrm{L}$, the proportions of liver pathological stage $>\mathrm{S} 1$ and $>$ S2 were $17.1 \%$ and $0.0 \%$. However, in patients with HBV DNA $\leq 4.362 \log _{10} \mathrm{IU} / \mathrm{mL}$, the proportions of liver pathological stage $>\mathrm{S} 1$ and $>\mathrm{S} 2$ were $65.8 \%$ and $38.4 \%$, and in combination with $\mathrm{ALT} \geq 20 \mathrm{IU} / \mathrm{L}$, the proportions of liver pathological stage $>\mathrm{S} 1$ and $>$ S2 were $68.8 \%$ and $25.0 \%$. These suggested that the ability of ALT based on the three preset ULNs and of HBV DNA with reference to the practical cutoff alone and in combination with ALT for excluding extensive liver fibrosis and cirrhosis is all very limited; however, the performances of HBsAg with the standard of the practical cutoff alone and in combination with ALT for excluding extensive liver fibrosis and cirrhosis are both almost excellent.

This study had some limitations. First, the study population was all patients undergoing liver biopsy, and most of the patients were adults, so the selection bias of patients cannot be completely excluded. Second, the sample size was relatively small, and the gender differences in the normal references of ALT were not considered, so the findings of this study may need to be further confirmed in different genders by expanding the sample size. Third, this study was a retrospective cross-sectional study, and its findings may also need to be further verified by retrospective or prospective follow-up studies.

\section{Conclusions}

In the subpopulation with possible high HBV replication, HBsAg and HBeAg instead of HBV DNA were significantly negatively correlated with ALT, and had very good and good performance in predicting "biochemical or pathological" significant hepatitis activity; in the subpopulation with possible low HBV replication, HBV DNA and HBeAg instead of HBsAg were significantly positively correlated with ALT, and had very good and good 
performance in predicting biochemically significant hepatitis activity. With the standard of HBsAg > $4.699 \log _{10} \mathrm{IU} / \mathrm{mL}$ and of ALT < $40 \mathrm{IU} / \mathrm{L}, \mathrm{HBsAg}$ alone and in combination with ALT had excellent performance in excluding HBeAg-positive extensive liver fibrosis and cirrhosis of HBeAg-positive chronic HBV infection.

Author Contributions: Conceptualization, Z.Z.; methodology, Z.Z.; formal analysis, Z.Z.; investigation, Z.Z., W.L. (Wei Lu), D.Z.; resources, Z.Z., W.L. (Wei Lu), D.Z., Y.F.; data curation, Z.Z., W.L. (Wei Lu), D.Z., Y.F.; writing-original draft preparation, Z.Z.; writing-review and editing, Z.Z., W.L. (Wei Lu), D.H., W.L. (Weijia Lin), L.Y., Y.F.; project administration, Z.Z., W.L. (Wei Lu); funding acquisition, Z.Z. All authors have read and agreed to the published version of the manuscript.

Funding: This research was funded by the "13th Five-year" National Science and Technology Major Project of China (2017ZX10203202), and Shanghai Municipal Hospital of Joint Research Projects in Emerging Cutting-Edge Technology (SHDC12016237).

Institutional Review Board Statement: This study was approved by the independent ethics committee of Shanghai Public Health Clinical Center of Fudan University (2018-S003-002, 2016-S046-02). The study was conducted according to the guidelines of the 2013 Declaration of Helsinki.

Informed Consent Statement: Written consent before liver biopsy was obtained from all patients involved in the study.

Data Availability Statement: Data are available on request due to restrictions, e.g., privacy or ethical.

Conflicts of Interest: The authors declare no conflict of interest. The funders had no role in the design of the study; in the collection, analyses, or interpretation of data; in the writing of the manuscript, or in the decision to publish the results.

\section{Appendix A. Further Explanation of Some Concepts, Research Background and Research Ideas of Our Manuscript}

Appendix A.1. Is the Naming of Different Phases in the Natural History of Chronic HBV Infection Reasonable in the Currently Existing Guidelines?

In the field of infectious diseases, colonization refers to the reproduction or "reproduction and metabolism" of microbials (viruses, subviruses and microorganisms) and tiny organisms on the surface or in the body of a macroorganism or a large organism. Colonization can be harmless. Detrimental colonization is called infection. In the process of infection, the insults of microbials and tiny organisms to macroorganisms or large organisms can result from products of the reproduction and metabolism of microorganisms and tiny organisms, and/or the innate and adaptive immunities of the macroorganism or large organism.

It has been confirmed that once HBV is colonized in human hepatocytes, it will cause injury to the liver. We have performed liver histological examination on more than 4000 patients with chronic HBV infection, including naïve patients and antiviral patients. With reference to the Scheuer standard, all (not almost all) patients with chronic HBV infection have varying degrees of liver necro-inflammation, including pathological grade G1, but can have no fibrosis, i.e., S0; we have also performed liver histological examination of healthy volunteers in another study of ours, who did not have hepatic necro-inflammation, that is, G0 did exist.

Therefore, the fact that the current guidelines with international influence, such as the AASLD 2018, the APASL 2015 and the WHO 2015, call the first phase of the natural history of chronic HBV infection "immune tolerance" is unreasonable; the fact that the EASL 2017 guidelines call the first and second phases of the natural history of chronic $\mathrm{HBV}$ infection "HBeAg-positive chronic infection" and "HBeAg-positive chronic hepatitis", respectively, is also unreasonable, because chronic $\mathrm{HBV}$ infection and chronic hepatitis $B$ are the same concept.

The first and second phases in the natural history of "chronic HBV infection" or "chronic hepatitis B" do exist. How should these two phases be named? We believe that the naming of the disease phase should be based on clinical perspectives (clinical 
characteristics as well as changes in biochemical, virological, immunological indicators and pathological parameters) rather than immunological or virological "mechanisms", because clinical findings are facts, and the immunological or virological mechanisms belong to inferences. In other words, the natural history of chronic hepatitis B is a practical concept rather than a theoretical concept.

Therefore, in this study, the first and second phases of the natural history of chronic HBV infection are called "non-significant hepatitis activity" and "significant hepatitis activity", and are clearly defined using biochemical or/and pathological parameters.

Appendix A.2. Is "Significant Hepatitis Activity" of Chronic HBV Infection the Same Concept as "Pathological Significant Liver Necro-Inflammation" or "Pathological Significant Liver Fibrosis"?

In the studies of developing and evaluating noninvasive indexes or mathematical models for pathological liver necro-inflammatory intensities or / and fibrosis levels, most investigators defined significant liver necro-inflammation and significant liver fibrosis as higher than or equal to G2 and S2. It is important to realize that, although patients with liver necro-inflammatory intensities between G1 and G2 and liver fibrosis levels between S1 and S2 are less common, it means that significant hepatitis activity has begun or has happened. Therefore, "pathological significant hepatitis activity" and "pathological significant liver necro-inflammation" or "pathological significant liver fibrosis" are not the same concept.

Therefore, in this study, "significant hepatitis activity" refers to "serum ALT higher than or equal to the upper limit of normal" or "liver pathological grade higher than G1 or/and liver pathological stage higher than S1", in which ALT is a sensitive indicator and pathological grade and stage are specific indicators. In patients with "non-significant hepatitis activity", the pathological grade should be lower than (rarely possible) or equal to G1 and the pathological stage should be lower than or equal to S1.

Appendix A.3. Have the Criteria for Different Phases of the Natural History of Chronic HBV Infection Defined by the Guidelines with International Influence Been Agreed on?

Among the four parameters of the criteria for different phases of the natural history of chronic HBV infection, which are serum HBeAg states, ALT levels, HBV DNA levels and liver histological changes, two key parameters have not been agreed on in the guidelines with important international influence. First, the upper limit of the normal for ALT remains controversial. The APASL 2015 and the EASL 2017 guidelines recommend the use of the traditional normal reference with ALT < 40 IU/L, the AASLD 2018 guidelines recommend the use of the normal reference with ALT lower than or equal to $35 \mathrm{IU} / \mathrm{L}$ for males and lower than or equal to $25 \mathrm{IU} / \mathrm{L}$ for females, and the WHO 2015 guidelines recommend the use of the normal reference with ALT lower than $30 \mathrm{IU} / \mathrm{L}$ for males and lower than 19 IU / L for females. Second, although the APASL 2015, EASL 2017, the AASLD 2018 and the WHO 2015 all believe that the HBV DNA levels of most HBeAg-negative patients with "significant hepatitis activity" are higher than $2 \times 10^{3} \mathrm{IU} / \mathrm{mL}$ and some HBeAg-negative patients with "significant hepatitis activity" are between $2 \times 10^{3}$ and $2 \times 10^{4} \mathrm{IU} / \mathrm{mL}$, but have serious divergences in HBV DNA levels to define HBeAg-positive patients with "significant hepatitis activity". The APASL 2015, EASL 2017, the AASLD 2018 and the WHO 2015 recommend that HBV DNA levels to define HBeAg-positive patients with "significant hepatitis activity" are lower than or equal to $2 \times 10^{7} \mathrm{IU} / \mathrm{mL}$, lower than or equal to $10^{7} \mathrm{IU} / \mathrm{mL}$, lower than or equal to $10^{6} \mathrm{IU} / \mathrm{mL}$ and lower than or equal to $2 \times 10^{5} \mathrm{IU} / \mathrm{mL}$.

One of the highlights of this study is that, without referring to any criteria recommended by the guidelines that have serious divergences, it affirms the validity of HBsAg as a "new parameter" and denies the reliability of HBV DNA as a "standard parameter" for distinguishing "non-significant hepatitis activity" from "significant hepatitis activity" in patients with HBeAg-positive chronic HBV infection. 
Appendix A.4. Do Serum HBsAg, HBeAg and HBV DNA Levels Evolve in the Same Direction as Serum ALT Levels and Liver Necro-Inflammatory Intensities or Fibrosis Levels?

In HBeAg-negative patients, ALT levels increase significantly with the increase in HBV DNA levels, and liver necro-inflammatory intensities or fibrosis levels also increase significantly with the increase in HBV DNA levels; however, ALT levels and liver necroinflammatory intensities or fibrosis levels do not necessarily increase significantly with the increase in HBsAg levels. In HBeAg-positive patients, the "high levels" of HBsAg, HBeAg and HBV DNA may show "normal" ALT, "slight" liver necro-inflammation and "no or slight" liver fibrosis, and the "medium to low" levels of HBsAg, HBeAg and HBV DNA mostly show "abnormally incresed" ALT, "significant" liver necro-inflammation or "significant" liver fibrosis. HBeAg-positive patients with "high levels" of HBsAg, HBeAg and HBV DNA have long been known as "immune tolerance", although it has lately been challenged. In fact, according to our experience, true "immune tolerance" does not exist.

The LOESS regression analyses in this study illustrated that, in HBeAg-positive patients with "high levels" of HBsAg, HBeAg and HBV DNA, ALT levels decrease significantly with the increase in $\mathrm{HBsAg}, \mathrm{HBeAg}$ and $\mathrm{HBV}$ DNA levels; however, in $\mathrm{HBeAg}$ positive patients with "medium to low levels" of HBeAg and HBV DNA, ALT levels increase significantly with the increase inHBeAg and HBV DNA levels, and with "medium to low level" of HBsAg, ALT levels do not necessarily increase significantly with the increase in HBsAg levels.

Appendix A.5. Why Should the Levels of HBsAg, HBeAg and HBV DNA Be Stratified in Patients with Chronic HBV Infection?

The stratification of HBsAg, HBeAg and HBV DNA levels is of great practical importance for the division of the natural history phases and individual management of the patients.

In either HBeAg-positive or HBeAg-negative patients, the delimitation criteria between low levels and medium to high levels of HBV DNA have reached a consensus, that is, HBV DNA less than $2 \times 10^{3} \mathrm{IU} / \mathrm{mL}$ or sometimes less than $2 \times 10^{4} \mathrm{IU} / \mathrm{mL}$ is defined as low levels, and higher than $2 \times 10^{3} \mathrm{IU} / \mathrm{mL}$ or sometimes higher than $2 \times 10^{4} \mathrm{IU} / \mathrm{mL}$ is defined as medium to high levels. However, the boundary standard between medium levels and high levels of HBV DNA remains controversial.

Most patients with low levels of HBV DNA, regardless of whether they areHBeAgpositive or HBeAg-negative, tend to have non-significant hepatitis activity, and whether to provide them with antiviral therapy needs to refer to the invasive or non-invasive evaluation of liver pathological changes. HBeAg-positive patients with medium levels of HBV DNA tend to have significant hepatitis activity, and may need antiviral therapy; however, those with high levels of HBV DNA are characterized by non-significant hepatitis activity, considering the accessibility of nucleoside/nucleotide drugs, and whether to provide them with antiviral therapy is the focus of debates at present. HBeAg-negative patients with both medium levels and high levels of HBV DNA tend to have significant hepatitis activity, and may need antiviral therapy.

So far, there are no clear division criteria for low, medium and high levels of HBsAg and HBeAg. Although EASL 2017 guidelines mentioned that the HBsAg level can be used as the basis for the classification of HBeAg-positive chronic infection (non-significant hepatitis activity) and chronic hepatitis (significant hepatitis activity), and HBeAg-negative chronic infection (non-significant hepatitis activity) and chronic hepatitis (significant hepatitis activity), which are described as high levels and high/intermediate levels, low levels and intermediate level, respectively, they did not give a specific "quantization standard". The main highlight and also the main purpose of this study is to clarify the effectiveness of HBsAg rather than HBV DNA in distinguishing HBeAg-positive non-significant hepatitis activity from significant hepatitis activity, that is, to clarify the boundary between high levels and medium to low levels of HBsAg. 
Appendix A.6. Based on the Existing Natural History Phase Standards, Can We Reasonably Evaluate the Performance of Serum HBsAg in Predicting Natural History Phases of Chronic HBV Infection?

There is an inherent correlation between HBsAg and HBV DNA. The parameters of the existing natural history phase standards cover HBV DNA. Although there is no agreement on the demarcation standards, as an essential parameter of natural history phase standards, HBV DNA has a preconceived superiority, that is, the performance of HBV DNA in predicting the natural history phases is preset as "best". Therefore, if HBsAg is evaluated with reference to the existing natural history phase standards, its performance may be underestimated in predicting the natural history phases.

Reasonable evaluation of HBsAg in predicting the natural history phases should only refer to serum biochemical or liver histological criteria free from HBV DNA. Although ALT can quickly reflect significant hepatitis activity, its upper limit of normal is still controversial; although liver histological changes can accurately reflect significant hepatitis activity, their change speed is too slow. Therefore, this study presets not only serum biochemical but also liver histological criteria, that is, "ALT greater than or equal to the upper limits of normal" and "pathological grade $>$ G1 or stage $>$ S1" are defined as "biochemical significant hepatitis activity" and "pathological significant hepatitis activity".

Appendix A.7. Taking All HBeAg-Positive Patients as a Whole, Is It Reasonable to Evaluate the Performance of Serum HBsAg in Predicting the Natural History Phases of Chronic HBV Infection?

If the demarcation between medium and high levels of HBV DNA can be used to distinguish natural history phases, the quantitative HBV DNA of HBeAg-positive patients should be divided into three levels of low, medium and high levels. Although both low and high levels of HBV DNA of HBeAg-positive patients tend to show non-significant hepatitis activity, with the increase in HBV DNA levels, the change direction of ALT levels and of hepatic necro-inflammation intensities and fibrosis levels in patients from low to medium levels of HBV DNA may be opposite to those in patients from medium to high levels of HBV DNA. Therefore, the demarcation between low levels and medium levels of HBV DNA should be carried out in the population with low to medium levels of HBV DNA, and that between medium and high levels of HBV DNA should be carried out in the population with medium to high levels of HBV DNA.

There are two sources of HBsAg: HBV covalently closed circular DNA and HBV DNA integrated into the host genome. The frequency of HBV DNA integrated into the host genome in HBeAg-negative patients is higher than that in HBeAg-positive patients, which means there is a stronger positive correlation between HBsAg and HBV DNA in HBeAg-positive than HBeAg-negative patients. Therefore, similar to the demarcation thinking between low and medium levels and between medium and high levels of HBV DNA, if HBsAg is evaluated based on all HBeAg-positive patients, that is, no stratification of HBsAg levels, its performance may also be underestimated in predicting the natural history phases.

One of the highlights of this study and also the prerequisite of this study is to divide the quantitative HBsAg, HBeAg and HBV DNA into "fuzzy" low to medium levels and "fuzzy" high levels according to the LOESS regression of ALT with HBsAg, HBsAg and HBV DNA, by observing the local change trends of ALT with HBsAg, HBsAg and HBV DNA, and to delimit low to medium levels of "HBsAg and HBeAg and HBV DNA" (fuzzy low to medium levels HBV replication) and high levels of "HBsAg or HBsAg or HBV DNA" (fuzzy medium to high levels HBV replication), which are called "possible low HBV replication" and "possible high HBV replication", respectively. Based on the populations with "possible low HBV replication" and "possible high HBV replication", the "rational cutoffs" and corresponding performance of HBsAg, HBeAg and HBV DNA in predicting non-significant hepatitis activity are explored and evaluated, respectively. 
Appendix A.8. Which of the Biochemical, Pathological and Virological Parameters Should Be the Gold Standard for Affirming Non-Significant Hepatitis Activity of HBeAg-Positive Chronic HBV Infection?

For HBeAg-positive patients, the liver pathological changes of non-significant hepatitis activity should be the "long-term stable" pathological grade of lower than or equal to G1 and "long-term stable" pathological stage of lower than or equal to S1. The pathological scoring standards that have been widely used at present, such as Scheuer, Ludwig, Ishak and METAVIR, have a high consistency. However, significant hepatitis activity does not mean that necro-inflammation and fibrosis are "constant or progressive". For example, in patients with early significant hepatitis activity, a pathological grade of higher than G1 or astage of higher than S1 does not necessarily occur; in a few patients with significant hepatitis activity, the pathological grade may never be higher than G1 and the stage may never be higher than S1; and in patients with late significant hepatitis activity, the high levels of pathological grade and stage may return to G1 and S1. Therefore, for HBeAgpositive patients, liver pathological changes are not sufficiently specific and sensitive in affirming non-significant hepatitis activity.

For HBeAg-positive patients, serum ALT of non-significant hepatitis activity should be maintained at "normal level" for a long time. However, the upper limit of normal for ALT remains controversial. Theoretically, the "abnormal increase" in ALT levels indicates significant hepatitis activity. However, the specificity and sensitivity for predicting significant hepatitis activity should be different with reference to different upper limits of normal. In fact, previous studies showed that about $10 \%$ of patients with liver cirrhosis with ALT $<40 \mathrm{IU} / \mathrm{L}$ were missed. The data of this study showed that, in patients with ALT $<40 \mathrm{IU} / \mathrm{L}, 73.9 \%$ of slight necro-inflammation (pathological grade of equal to G1) and $52.9 \%$ of slight or no fibrosis (pathological stage of lower than or equal to S1) were correctly diagnosed, and $9.4 \%$ and $11.6 \%$ of patients with extensive fibrosis and cirrhosis, i.e., $21.0 \%$ of "patients with extensive fibrosis and cirrhosis", were missed; in patients with ALT $<20$ IU / L, 83.3\% of slight necro-inflammation (pathological grade of equal to G1) and $55.6 \%$ of slight or no fibrosis (pathological stage of lower than or equal to S1) were correctly diagnosed, and $5.6 \%$ and $5.6 \%$ of patients with extensive fibrosis and cirrhosis, i.e., $11.2 \%$ of "patients with extensive fibrosis and cirrhosis", were missed. Therefore, for HBeAg-positive patients, the "abnormal increase" in serum ALT levels is also not sufficiently specific and sensitive in affirming non-significant hepatitis activity.

Therefore, for HBeAg-positive patients, new indicators need to be developed to make up for the insufficiency of sensitivity and specificity of both liver pathological changes and ALT levels in affirming non-significant hepatitis activity, so as to more accurately distinguish non-significant hepatitis activity and significant hepatitis activity.

Clinical practice and clinical studies have found and confirmed that, for $\mathrm{HBeAg}$ positive patients, high levels of HBV DNA, HBeAg and HBsAg are related to "long-term stable" non-significant hepatitis activity. However, the cutoffs of "high levels" of HBV DNA, HBeAg and HBsAg to define non-significant hepatitis activity and their corresponding performance are not clear. Although "high levels" of HBV DNA have been used as a key parameter to define non-significant hepatitis activity, so far, the standards of "high level" of HBV DNA have not been unified. However, whether patients are HBeAg-positive or HBeAg-negative, the standard of "low levels" of HBV DNA for diagnosing non-significant hepatitis activity has been agreed on.

The main highlight of this study was the findings that high levels of $\mathrm{HBsAg}$, rather than high levels of HBV DNA, are a very good parameter for predicting non-significant hepatitis activity in HBeAg-positive patients, and we put forward a reasonable cutoff of HBsAg for diagnosing non-significant hepatitis activity in HBeAg-positive patients. 


\section{References}

1. Liu, J.; Liang, W.; Jing, W.; Liu, M. Countdown to 2030: Eliminating hepatitis B disease, China. Bull. World Health Organ. 2019, 97, 230-238. [CrossRef]

2. Sarin, S.K.; Kumar, M.; Lau, G.K.; Abbas, Z.; Chan, H.L.; Chen, C.J.; Chen, D.S.; Chen, H.L.; Chen, P.J.; Chien, R.N.; et al. Asian-Pacific clinical practice guidelines on the management of hepatitis B: A 2015 update. Asian-Pacific clinical practice guidelines on the management of hepatitis B: A 2015 update. Hepatol. Int. 2016, 10, 1-98. [CrossRef] [PubMed]

3. Lampertico, P.; Agarwal, K.; Berg, T.; Buti, M.; Janssen, H.L.A.; Papatheodoridis, G.; Zoulim, F. EASL 2017 Clinical Practice Guidelines on the management of hepatitis B virus infection. J. Hepatol. 2017, 67, 370-398. [CrossRef]

4. Terrault, N.A.; Lok, A.S.F.; McMahon, B.J.; Chang, K.M.; Hwang, J.P.; Jonas, M.M.; Brown, R.S., Jr.; Bzowej, N.H.; Wong, J.B. Update on prevention, diagnosis, and treatment of chronic hepatitis B: AASLD 2018 hepatitis B guidance. Hepatology 2018, 67, 1560-1599. [CrossRef] [PubMed]

5. Kolahdoozan, S.; Mirminachi, B.; Sepanlou, S.G.; Malekzadeh, R.; Merat, S.; Poustchi, H. Normal limits of serum alanine aminotransferase in healthy population: A systematic review. Middle East J. Dig. Dis. 2020, 12, 194-205. [CrossRef]

6. Kumar, M.; Sarin, S.K.; Hissar, S.; Pande, C.; Sakhuja, P.; Sharma, B.C.; Chauhan, R.; Bose, S. Virological and histological features of chronic hepatitis B virus infected asymptomatic patients with persistently normal ALT. Gastroenterology 2008, 134, 1376-1384. [CrossRef] [PubMed]

7. Gui, H.L.; Wang, H.; Yang, Y.H.; Wu, Y.W.; Zhou, H.J.; Guo, S.M.; Lin, L.Y.; Wang, L.; Cai, W.; Chen, R.; et al. Significant histopathology in Chinese chronic hepatitis B patients with persistently high-normal alanine aminotransferase. J. Viral. Hepat. 2010, 17 (Suppl. S1), 44-50. [CrossRef]

8. Liao, B.; Wang, Z.; Lin, S.; Xu, Y.; Yi, J.; Xu, M.; Huang, Z.; Zhou, Y.; Zhang, F.; Hou, J. Significant fibrosis is not rare in Chinese chronic hepatitis B patients with persistent normal ALT. PLoS ONE 2013, 8, e78672. [CrossRef]

9. Xing, Y.F.; Zhou, D.Q.; He, J.S.; Wei, C.S.; Zhong, W.C.; Han, Z.Y.; Peng, D.T.; Shao, M.M.; Sham, T.T.; Mok, D.K.; et al. Clinical and histopathological features of chronic hepatitis B virus infected patients with high HBV-DNA viral load and normal alanine aminotransferase level: A multicentre-based study in China. PLoS ONE 2018, 13, e0203220. [CrossRef]

10. Kumar, M.; Sarin, S.K. Hepatitis B virus immunotolerant patients: Need to differentiate patients with or without liver disease. Gastroenterology 2009, 137, 742-743. [CrossRef]

11. Zhang, Z.Q.; Shi, B.S.; Lu, W.; Liu, D.; Huang, D.; Feng, Y. Quantitative HBcrAg and HBcAb versus HBsAg and HBV DNA in predicting liver fibrosis levels of chronic hepatitis B patients. Gastroenterol. Hepatol. 2020, 43, 526-536. [CrossRef] [PubMed]

12. Hadziyannis, E.; Laras, A. Viral biomarkers in chronic HBeAg negative HBV infection. Genes 2018, 9, 469. [CrossRef] [PubMed]

13. Nguyen, T.; Thompson, A.J.; Bowden, S.; Croagh, C.; Bell, S.; Desmond, P.V.; Levy, M.; Locarnini, S.A. Hepatitis B surface antigen levels during the natural history of chronic hepatitis B: A perspective on Asia. J. Hepatol. 2010, 52, 508-513. [CrossRef] [PubMed]

14. Jaroszewicz, J.; Calle Serrano, B.; Wursthorn, K.; Deterding, K.; Schlue, J.; Raupach, R.; Flisiak, R.; Bock, C.T.; Manns, M.P.; Wedemeyer, H.; et al. Hepatitis B surface antigen (HBsAg) levels in the natural history of hepatitis B virus (HBV)-infection: A European perspective. J. Hepatol. 2010, 52, 514-522. [CrossRef] [PubMed]

15. Zhang, Z.Q.; Wang, Y.B.; Lu, W.; Liu, D.P.; Shi, B.S.; Zhang, X.N.; Huang, D.; Li, X.F.; Zhou, X.L.; Ding, R.R. Performance of hepatitis B core-related antigen versus hepatitis B surface antigen and hepatitis B virus DNA in predicting HBeAg-positive and HBeAg-negative chronic hepatitis. Ann. Lab. Med. 2019, 39, 67-75. [CrossRef]

16. Zhang, Z.Q.; Lu, W.; Wang, Y.B.; Weng, Q.C.; Zhang, Z.Y.; Yang, Z.Q.; Feng, Y.L. Measurement of the hepatitis B core-related antigen is valuable for predicting the pathological status of liver tissues in chronic hepatitis B patients. J. Virol. Methods 2016, 235, 92-98. [CrossRef]

17. Seto, W.K.; Wong, D.K.; Fung, J.; Ip, P.P.; Yuen, J.C.; Hung, I.F.; Lai, C.L.; Yuen, M.F. High hepatitis B surface antigen levels predict insignificant fibrosis in hepatitis B e antigen positive chronic hepatitis B. PLoS ONE 2012, 7, e43087. [CrossRef]

18. Cornberg, M.; Wong, V.W.S.; Locarnini, S.; Brunetto, M.; Janssen, H.L.A.; Chan, H.L. The role of quantitative hepatitis B surface antigen revisited. J. Hepatol. 2017, 66, 398-411. [CrossRef]

19. Pollicino, T.; Caminiti, G. HBV-integration studies in the clinic: Role in the natural history of infection. Viruses 2021, $13,368$. [CrossRef]

20. Mak, L.Y.; Seto, W.K.; Fung, J.; Yuen, M.F. Use of HBsAg quantification in the natural history and treatment of chronic hepatitis B. Hepatol. Int. 2020, 14, 35-46. [CrossRef]

21. Zhang, Z.Q.; Zhang, X.N.; Lu, W.; Wang, Y.B.; Weng, Q.C.; Feng, Y.L. Distinct patterns of serum hepatitis B core-related antigen during the natural history of chronic hepatitis B. BMC Gastroenterol. 2017, 17, 140. [CrossRef]

22. Zhang, Z.Q.; Shi, B.S.; Lu, W.; Liu, D.; Huang, D.; Feng, Y. Quantitative anti-HBc in liver pathological states in patients with chronic hepatitis B virus infection. Can. J. Infect. Dis. Med. Microbiol. 2019, 2019, 6545642. [CrossRef] [PubMed]

23. Brunt, E.M. Grading and staging the histopathological lesions of chronic hepatitis: The Knodell histology activity index and beyond. Hepatology 2000, 31, 241-246. [CrossRef] [PubMed]

24. Mason, W.S.; Gill, U.S.; Litwin, S.; Zhou, Y.; Peri, S.; Pop, O.; Hong, M.L.W.; Naik, S.; Quaglia, A.; Bertoletti, A.; et al. HBV DNA integration and clonal hepatocyte expansion in chronic hepatitis B patients considered immune tolerant. Gastroenterology 2016, 151, 986-998.e4. [CrossRef]

25. Seto, W.K.; Yuen, M.F. Viral hepatitis: 'Immune tolerance' in HBV infection: Danger lurks. Nat. Rev. Gastroenterol. Hepatol. 2016, 13, 627-628. [CrossRef] 
26. Kennedy, P.T.F.; Litwin, S.; Dolman, G.E.; Bertoletti, A.; Mason, W.S. Immune tolerant chronic hepatitis B: The unrecognized risks. Viruses 2017, 9, 96. [CrossRef] [PubMed]

27. Hong, M.; Bertoletti, A. Tolerance and immunity to pathogens in early life: Insights from HBV infection. Semin. Immunopathol. 2017, 39, 643-652. [CrossRef]

28. Lee, H.W.; Chan, H.L.Y. Unresolved issues of immune tolerance in chronic hepatitis B. J. Gastroenterol. 2020, 55, 383-389. [CrossRef]

29. Milich, D.R. The concept of immune tolerance in chronic hepatitis B virus infection is alive and well. Gastroenterology 2016, 151, 801-804. [CrossRef]

30. Han, Q.; Lan, P.; Zhang, J.; Zhang, C.; Tian, Z. Reversal of hepatitis B virus-induced systemic immunetolerance by intrinsic innate immune stimulation. J. Gastroenterol. Hepatol. 2013, 28 (Suppl. S1), 132-137. [CrossRef]

31. Guidotti, L.G.; Isogawa, M.; Chisari, F.V. Host-virus interactions in hepatitis B virus infection. Curr. Opin. Immunol. 2015, 36, 61-66. [CrossRef] [PubMed]

32. Peeridogaheh, H.; Meshkat, Z.; Habibzadeh, S.; Arzanlou, M.; Shahi, J.M.; Rostami, S.; Gerayli, S.; Teimourpour, R. Current concepts on immunopathogenesis of hepatitis B virus infection. Virus Res. 2018, 245, 29-43. [CrossRef] [PubMed]

33. Velazquez, V.M.; Grakoui, A. Immune quiescence and hepatitis B virus: Tolerance has its limits. Gastroenterology 2012, 143, 529-532. [CrossRef] [PubMed]

34. Li, T.Y.; Yang, Y.; Zhou, G.; Tu, Z.K. Immune suppression in chronic hepatitis B infection associated liver disease: A review. World J. Gastroenterol. 2019, 25, 3527-3537. [CrossRef] [PubMed]

35. Kramvis, A.; Kostaki, E.G.; Hatzakis, A.; Paraskevis, D. Immunomodulatory function of HBeAg related to short-sighted evolution, transmissibility, and clinical manifestation of hepatitis B virus. Front. Microbiol. 2018, 9, 2521. [CrossRef]

36. Mannan, R.; Misra, V.; Misra, S.P.; Singh, P.A.; Dwivedi, M. A comparative evaluation of scoring systems for assessing necroinflammatory activity and fibrosis in liver biopsies of patients with chronic viral hepatitis. J. Clin. Diagn. Res. 2014, 8, FC08-12. [CrossRef] 